\title{
Temperature-mediated variation in early life history traits and recruitment success of the coral reef fish Thalassoma bifasciatum in the Florida Keys
}

\author{
Su Sponaugle ${ }^{1, *}$, Kirsten Grorud-Colvert $^{1}{ }^{1}$ Deanna Pinkard ${ }^{1,2}$ \\ ${ }^{1}$ Marine Biology and Fisheries Division, Rosenstiel School of Marine and Atmospheric Science, University of Miami, \\ 4600 Rickenbacker Causeway, Miami, Florida 33149-1098, USA \\ ${ }^{2}$ Present address: Fisheries Resources Division, National Oceanic \& Atmospheric Administration, \\ Southwest Fisheries Science Center, 8604 La Jolla Shores Drive, La Jolla, California 92037, USA
}

\begin{abstract}
Thirteen cohorts of the Caribbean reef fish Thalassoma bifasciatum were collected over 4 yr (2000 to 2003) in the upper Florida Keys, USA. Juvenile fish were censused and collected from replicate reefs shortly after settlement. The otoliths were examined to obtain early life history information such as timing of spawning, larval growth, pelagic larval duration, size-at-age, timing of settlement, and juvenile age and growth. Mean water temperature over the reef during the larval period explained $78 \%$ of the variation in larval growth among cohorts. Faster-growing warm-water fish had shorter pelagic larval durations (PLD), and larval growth explained $85 \%$ of the variation in PLD. Relative (otolith) size-at-settlement was a function of larval growth as well as PLD: settling larvae were largest at intermediate water temperatures. Early juvenile growth was also directly related to water temperature, which enabled smaller warm-water settlers to grow rapidly and eventually exceed juvenile size-atage of the cooler-water cohorts. Cohorts encountering intermediate water temperatures remained the largest throughout early juvenile life on the reef. The relative size of recruitment events could not be explained by any larval or juvenile trait, nor by water temperature. Recruitment was generally low for cool-water cohorts but quite variable among warm-water cohorts. This may be due to increased difficulty in sustaining high growth rates in warm water (i.e. beyond a threshold temperature of $28.5^{\circ} \mathrm{C}$ ) or the interference of mesoscale advection processes. When 4 cohorts that settled during the passage of mesoscale eddies were omitted from the analysis, $61 \%$ of the variation in recruitment magnitude could be explained by water temperature alone. The dynamic oceanographic setting of the Florida Keys may obscure the relationship between seasonal water temperature, early life history traits, and magnitude of recruitment events.
\end{abstract}

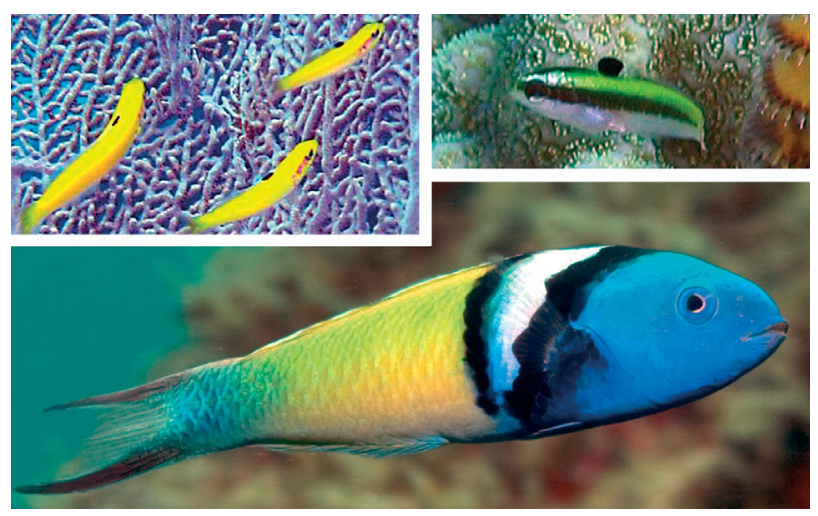

Thalassoma bifasciatum. New recruit, older juveniles, and terminal phase male (counterclockwise from upper right). Water temperature largely determined growth rates and duration of the pelagic phase in bluehead wrasse larvae. The relationship between water temperature and fish recruitment was decoupled by variable feeding success in warm oligotrophic water or by transport due to mesoscale oceanographic circulation.

Photos: Evan D'Alessandro

KEY WORDS: Reef fish settlement and recruitment . Larval and juvenile growth · Pelagic larval duration · Otoliths · Water temperature

Resale or republication not permitted without written consent of the publisher

\section{INTRODUCTION}

Environmentally-mediated differences in somatic growth are well known in temperate marine fishes. Warmer water temperatures induce higher metabolic 
rates in poikilotherms and result in generally higher growth rates (Houde 1989, Blaxter 1992, Benoît et al. 2000). The relationship between growth, size, and mortality has been widely examined for larvae of economically important temperate species in the interest of understanding stock-recruit issues (e.g. Chambers \& Leggett 1987, Rutherford \& Houde 1995, Campana 1996, Otterlei et al. 1999). While growth must be sustained with adequate food, water temperature plays a central role in determining growth rates (Houde 1989, Pepin 1991, Rombough 1997). Growth of larvae of tropical species has received less attention (Cowen \& Sponaugle 1997) and due to substantially less seasonal fluctuation in water temperature, is generally considered to be less variable (Houde 1974, 1989).

Recent otolith-based field studies have begun to explore the extent and causes of variability in larval growth of tropical marine fishes. In a study combining field-collected and laboratory-reared goatfish, McCormick \& Molony (1995) demonstrated that small temperature changes accounted for $30 \%$ of the variation in larval growth. Water temperature similarly explained $30 \%$ (and food availability only 3.5 to $4.1 \%$ ) of the variation in larval growth of a damselfish in Western Australia (Meekan et al. 2003). Controlled laboratory experiments further highlight the role of temperature, maternity, and paternity in influencing larval growth rates of a tropical damselfish (Green \& Fisher 2004, Green \& McCormick 2005). In Barbados, significant differences in larval growth, pelagic larval duration (PLD), and relative condition at settlement for wrasse cohorts were thought to be due to changes in food supply (Searcy \& Sponaugle 2000), including those resulting from encounter with low-salinity eddies shed from the retroflexion of the North Brazil Current (Sponaugle \& Pinkard 2004a).

Increasing evidence demonstrates that similar to temperate species (e.g. Meekan \& Fortier 1996, Hare \& Cowen 1997, Takasuka et al. 2003), variation in early life history traits underlies selective mortality of tropical larvae or juveniles with particular traits (Searcy \& Sponaugle 2001, Vigliola \& Meekan 2002, McCormick \& Hoey 2004). Recently, a substantial portion of the variation in the magnitude of the settlement of 2 coral reef fishes to Panama was shown to be explained by variation in growth during particular windows in larval life (Bergenius et al. 2002, Wilson \& Meekan 2002). Combined, the above studies represent a subtle shift in research of tropical reef fish recruitment from largely transport-dominated processes (see Cowen 2002 for review) towards more growth-related processes as mechanisms underlying patterns of population replenishment. Yet, clearly, advective processes can play an important role in reef fish settlement, influencing the magnitude and/or temporal pattern of settlement (e.g.
Milicich 1994, Thorrold et al. 1994, Kingsford \& Finn 1997, Sponaugle \& Pinkard 2004b, Suthers et al. 2004, Sponaugle et al. 2005). Environmental and oceanographic processes both transport larvae as well as influence growth-related processes. Bergenius et al. (2005) used a combination of environmental variables to explain 13 to $38 \%$ of the variation in larval growth and settlement magnitude of the acanthurid Acanthurus chirurgus. These studies together demonstrate that both transport- and growth-related processes can influence the magnitude of recruitment of tropical reef fishes. However, much additional work is needed in a diversity of systems and species to advance our knowledge of the relative role of these processes and the extent, causes, and consequences of variation in early life history traits of tropical reef fishes.

This study was designed to examine variability in the early life history traits of a common CaribbeanWestern Atlantic reef fish in the Florida Keys. The reefs of the Florida Keys support a typical suite of coral reef fish species despite their subtropical location, where water temperatures vary $\sim 10^{\circ} \mathrm{C}$ seasonally. In addition, the reefs lie at the dynamic interface between a shallow estuarine system and a major western boundary current. The biological and physical mechanisms by which these populations are replenished are not well known, nor are the relationships between the traits exhibited by young fish and recruitment success.

\section{MATERIALS AND METHODS}

Study site and physical data. The spur and groove coral reefs of the Florida Keys lie $\sim 10 \mathrm{~km}$ offshore, along the edge of the Florida Current (FC). The FC enters the Straits of Florida (SOF) from the Gulf of Mexico Loop Current or, occasionally, directly from the Yucatan Current. It is then pinched between Florida and Cuba, Cay Sal Bank, and the Bahamas as it turns northward and eventually becomes the Gulf Stream farther north (see map in Lee et al. [1994]). Passage of the FC through the SOF is rapid (mean speeds = $160 \mathrm{~cm} \mathrm{~s}^{-1}$; Richardson et al. 1969), and the frontal boundary is characterized by frontal meanders and mesoscale and submesoscale eddies (Lee \& Williams 1999). The recirculation and shedding of major eddies, including a coastal countercurrent, have previously been hypothesized to play an important role in the population replenishment of benthic marine organisms (Lee et al. 1994). Nearshore passage of a mesoscale eddy has recently been shown to deliver a large pulse of settlement-stage reef fish larvae to upper Keys reefs (Sponaugle et al. 2005); however, in other situations, eddies may advect larvae out of the system (D'Alessandro 2005). 
Information on the timing of eddy passage was obtained from other concurrent studies using current meters and satellite imagery (Sponaugle et al. 2003, 2005, D'Alessandro 2005). Additional ocean color imagery (obtained from the MODIS high-resolution satellite: http://modis.marine.usf.edu/index.html) was examined directly for several short periods not covered by these other studies. Three day composites of ocean color images were examined for the presence of mesoscale eddies in the vicinity of the study sites (e.g. see Sponaugle et al. 2005). To further characterize the physical environment, daily water temperature data were obtained from 2 sources: the National Underwater Research Center provided water temperature data measured continuously at $21 \mathrm{~m}$ at Conch Reef (24 $59^{\prime} \mathrm{N}$, $80^{\circ} 25^{\prime} \mathrm{W}$ ), and sea surface temperature (SST) data for the FC were obtained from SST images from the MODIS high-resolution satellite.

Study species. Thalassoma bifasciatum (Bloch), the bluehead wrasse, is a common coral reef fish found throughout the Caribbean. It spawns daily (Warner \& Robertson 1978) and pelagic larvae spend $\sim 50 \mathrm{~d}$ in the plankton before settling back to the reef (Victor 1986a, Sponaugle \& Cowen 1997). Settlement generally occurs in pulses associated with the third quarter or new moons (Victor 1986b, Sponaugle \& Cowen 1997, Robertson et al. 1999). Larvae settle to the sand near reefs and remain buried for 3 to $5 \mathrm{~d}$ until metamorphosis is complete, and fully pigmented juveniles emerge onto the reef (Victor 1982). These phases and transitions between phases are recorded in the otoliths, or ear stones. Increments are deposited daily (Victor 1982a), and the relationship between body length and otolith length is strongly correlated (Victor 1986a, Masterson et al. 1997, Sponaugle \& Cowen 1997, Searcy \& Sponaugle 2001). The width between successive increments provides a relative measure of somatic growth (Searcy \& Sponaugle 2000, 2001).

Sampling. Cohorts (fish settling within a single lunar cycle) of newly-settled Thalassoma bifasciatum were censused and collected monthly from replicate sites along the offshore bank reefs of the upper Florida Keys. Pickles (PI; 245 59.2' N, $80^{\circ} 24.9^{\prime} \mathrm{W}$ ), Sand Island (SI; $25^{\circ} 01.1^{\prime} \mathrm{N}$, $\left.80^{\circ} 22.1^{\prime} \mathrm{W}\right)$, and North French (NF; $25^{\circ} 01.2^{\prime} \mathrm{N}, 80^{\circ} 26.5^{\prime} \mathrm{W}$ ) are located within the Florida Keys National Marine Sanctuary (FKNMS), but the collection of new recruits is permitted (see Sponaugle et al. 2005 for map of study sites). Density estimates were occasionally obtained from Sanctuary Protected Areas of the FKNMS
(Molasses: $\mathrm{MO} ; 25^{\circ} 00.74^{\prime} \mathrm{N}, 80^{\circ} 22.40^{\prime} \mathrm{W}$; and French: $\mathrm{FR}_{i} 25^{\circ} 02.06^{\prime} \mathrm{N}, 80^{\circ} 21.00^{\prime} \mathrm{W}$ ), but no fish were collected. Censuses and collections were always made at PI, but the second replicate site varied primarily between NF and SI (Table 1).

The density of new recruits $(\leq 20 \mathrm{~mm}$ standard length, SL) was estimated by counting the number of juveniles within 10 to 30 replicate $5 \times 1 \mathrm{~m}$ quadrats. The number of quadrats sampled each census varied due to generally smaller than expected settlement events, weather constraints, and other sampling needs (i.e. over time we increased the number of quadrats sampled in an attempt to improve our ability to measure mortality for a concurrent study). Quadrats were placed haphazardly on the spurs along the forereef and new recruits were counted and collected by 2 divers. Recruits were collected using hand nets and the anesthetic quinaldine. Additional recruits were collected at the end of the census to provide sufficient sample sizes for otolith analysis. Collected recruits were preserved in $95 \%$ ethanol.

Most of the cohorts were censused and collected during the late spring and summer months of 2000 (6 cohorts) and 2001 (4 cohorts), but additional collections were made during the late fall and winter during 2002 ( 2 cohorts) and 2003 (1 cohort) to expand the seasonal comparison (Table 1). Density estimates were made for all but the first cohort in 2000.

Otolith analysis. Prior to dissection, the SL of all collected recruits was measured to the nearest $0.1 \mathrm{~mm}$, with the aid of a Leica MZ12 dissecting microscope
Table 1. Thalassoma bifasciatum. Summary of cohort sampling. Survey sites, collection and census dates, number of quadrats for density estimates, and number of fish aged for each cohort (coded alphanumerically to distinguish cohorts used in a separate study). Analysis of early life history traits was based only on fish $\leq 8 \mathrm{~d}$ old post-emergence, following metamorphosis. $\mathrm{PI}=$ Pickles Reef, NF = North of French Reef, MO = Molasses Reef, FR = French Reef, SI = Sand Island Reef

\begin{tabular}{|c|c|c|c|c|c|}
\hline Cohort & $\begin{array}{c}\text { Survey } \\
\text { reef(s) }\end{array}$ & $\begin{array}{c}\text { Census \& } \\
\text { collection dates } \\
(\mathrm{mo} / \mathrm{d} / \mathrm{yr})\end{array}$ & $\begin{array}{l}\text { Number of } \\
\text { quadrats } \\
\text { site }^{-1}\end{array}$ & $\begin{array}{l}\text { Fish } \\
\text { aged }\end{array}$ & $\begin{array}{l}\text { Fish } \\
\leq 8 \mathrm{~d} \\
\text { old }\end{array}$ \\
\hline A & PI & $4 / 21 / 00$ & $*$ & 30 & 19 \\
\hline 1 & $\mathrm{PI}, \mathrm{NF}$ & $5 / 12-13 / 00$ & 10 & 27 & 27 \\
\hline 3 & PI & $7 / 1 / 00 \& 7 / 5 / 00$ & 10 & 29 & 29 \\
\hline 4 & $\mathrm{PI}, \mathrm{NF}$ & $7 / 28 / 00$ & 15 & 36 & 36 \\
\hline B & PI, NF & $8 / 14 / 00$ & 15 & 31 & 30 \\
\hline 6 & $\mathrm{PI}, \mathrm{NF}$ & $9 / 1 / 00$ & 15 & 51 & 51 \\
\hline $\mathrm{C}$ & $\mathrm{PI}, \mathrm{MO}$ & 4/26/01 & 30 & 30 & 24 \\
\hline 7 & $\mathrm{PI}, \mathrm{MO}, \mathrm{FR}, \mathrm{SI}$ & $5 / 25-26 / 01$ & 30 & 26 & 26 \\
\hline 8 & PI, MO & 8/14/01 & 20 & 47 & 33 \\
\hline $\mathrm{D}$ & SI & $9 / 21 / 01$ & 15 & 29 & 26 \\
\hline $\mathrm{E}$ & PI, SI & $10 / 7 / 02$ & 20 & 29 & 23 \\
\hline $\mathrm{F}$ & PI, SI & $12 / 3 / 02 \& 12 / 6 / 02$ & 15 & 54 & 32 \\
\hline 10 & $\mathrm{PI}, \mathrm{SI}$ & $2 / 5 / 03$ & 20 & 40 & 28 \\
\hline
\end{tabular}


attached to a Dage MTI video camera that passed the image into a computer equipped with a frame grabber and Image Pro-Plus 4.5 image analysis software (Media Cybernetics). Both sagittae and lapilli were dissected out using standard techniques and placed on a microscope slide in drops of immersion oil and allowed to clear for 15 to $30 \mathrm{~d}$. Otoliths were read at $400 \times$ oil immersion magnification through a Leica DMLB microscope, equipped with a polarizing filter between the light source and the first stage. As above, the microscope image was transferred through a video camera and frame grabber to the Image Pro-Plus 4.5 software where it was sharpened and analyzed.

Sagittae were analyzed by selecting the longest otolith radius and enumerating each larval and juvenile increment as well as the transitional marks indicating settlement and emergence (see Sponaugle \& Pinkard 2004a). Metamorphosis is indicated by a wide band separating the larval and juvenile increments. These features enabled the measurement of the following early life history traits for each fish: timing of spawning, larval growth (increment widths), timing of settlement, PLD, otolith size-at-age, and juvenile (postemergence, following metamorphosis) age and early growth. Estimates of PLD and the timing of spawning included the addition of $2 \mathrm{~d}$ to the number of larval increments to account for time to hatch.

Both sagittae were examined during each read and the clearest sagitta was selected for increment interpretation. Identification of increments along the longest otolith axis was made using information from the sharpened images as well as from other parts of the otolith viewed directly through the microscope. Each sagitta was read blind (i.e. unknown sample identification) and once all reads were complete, the saved digital images were re-examined blind to confirm interpretations (Sponaugle \& Pinkard 2004a).

In total, 459 fish were aged, with a mean of 35 per cohort. To minimize the potential influence of selective juvenile mortality, we used only fish $\leq 8 \mathrm{~d}$ postemergence in the comparisons of early life history traits. As a result, a mean of 30 (range 19 to 51) fish was used from each cohort (Table 1).

Data analysis. Otolith aging was used to backcalculate the timing of settlement and spawning for each collected recruit to identify how consistent the timing of events was and whether any temporal variation was related to differences in early life history traits (i.e. larval growth and PLD). Grouping calendar days by phase of the lunar cycle (with Day 1 as the new moon), patterns of settlement and spawning for each cohort were described using Rayleigh circular statistics (Batschelet 1981).

Otolith-derived early life history traits were compared among cohorts using standard ANOVA tech- niques (SYSTAT version 11.0, Wilkinson 1992) where single measures were obtained for each individual fish (PLD and otolith size-at-settlement and at Day 4 postemergence). Where multiple measures were taken from each fish (e.g. otolith increment widths), only specific points in larval and juvenile life (i.e. at 10, 20, $30 \mathrm{~d}$ larval age and $4 \mathrm{~d}$ post-emergence) were compared using separate ANOVA tests. This avoided the problem of a lack of independence, as only 1 measurement was used from each fish in each test. When significant differences occurred among cohorts, Tukey post-hoc multiple comparisons were performed to identify where significant differences occurred. General relationships among early life history traits were examined by standard least-squares regression techniques (SYSTAT). For relationships that were not described by a simple linear relationship, a polynomial regression was used.

To corroborate that observed differences in otolith radii-at-settlement reflected real differences in somatic size, we selected the very youngest recruits ( 0 to $1 \mathrm{~d}$ old post-settlement, closest to emergence) and compared the relative otolith radii-at-settlement and relative SL of fast growers (mean increment width = $4.3 \mu \mathrm{m}, \mathrm{PLD}=39$ to $45 \mathrm{~d}$ ) versus slow growers (mean increment width $=3.8 \mu \mathrm{m}$, PLD $=50$ to $69 \mathrm{~d}$ ) using $t$-tests. These categories were defined to provide the largest sample sizes in each category ( $\mathrm{n}=14$ and 12, respectively).

To identify any relationship between ambient water temperature and larval and juvenile growth, we regressed mean otolith increment width for each cohort against ambient near-reef water temperature for the period being examined. We also compared cohort-specific otolith growth to surface water temperatures in the FC obtained from sea surface temperature (SST) images, in case larvae were delivered to reefs via the FC. Early juvenile growth was similarly compared to both near-reef and offshore FC mean daily water temperatures.

We examined the relationship between early life history traits and cohort density by first comparing densities among replicate sites using nonparametric ANOVA (Kruskal-Wallis) techniques. Because there were no significant differences in cohort densities among replicate sites for all but one cohort (cohort 6 : Kruskal-Wallis $\mathrm{p}<0.05$, mean of means used in this case; all other cohorts: Kruskal-Wallis p > 0.05), densities were pooled among sites. A mean number of recruits $\mathrm{m}^{-2}$ of reef was obtained for each settlement event. Mean cohort-specific densities were regressed against mean cohort-specific early life history traits (mean larval otolith increment widths over the entire larval period, during separate $10 \mathrm{~d}$ intervals, and for 1 and 2 wk prior to settlement; mean PLD; mean otolith 
size at settlement; and mean juvenile otolith increment width during the first $4 \mathrm{~d}$ on the reef). Densities were also regressed against mean water temperature.

To examine whether any relationships between early life history traits and recruitment were influenced by the nearshore passage of recirculating oceanographic features (mesoscale frontal eddies), all regressions were repeated after removal of cohorts that began settling during or within $5 \mathrm{~d}$ of the passage of mesoscale eddies by the study sites. Physical features such as mesoscale eddies have the potential to deliver large pulses of settlement stage larvae (Sponaugle et al. 2005) or flush larvae away from settlement habitat (D'Alessandro 2005), thus their nearshore passage could decouple any relationship between growth rate and recruitment magnitude.

\section{RESULTS}

Thalassoma bifasciatum settles and recruits to the upper Florida Keys year-round. While it was not our goal to census every recruited cohort and describe overall recruitment patterns, settlement of the 13 cohorts censused and collected during this study occurred primarily during the third quarter and new moons (Fig. 1a). Only 4 cohorts differed from this general pattern: cohorts A and B settled on the first quarter moon, and cohorts 4 and 8 settled a few days earlier (between the full and third quarter moons). Backcalculated spawning of successful recruits was more variable than settlement and occurred over almost all periods of the lunar cycle; however, it was generally concentrated between the first quarter and full moons (Fig. 1b). Spawning of cohorts 10 and F was not significantly concentrated during any portion of the lunar month, cohort 4 was spawned early between the new and first quarter moons, and mean spawning of cohorts $A, B$, and D occurred slightly late, just after the full moon.

The 13 cohorts of Thalassoma bifasciatum that recruited to the upper Florida Keys varied in all of the early life history traits examined (Table 2). Larval
Table 2. Thalassoma bifasciatum. Mean values of early life history traits by cohort arranged in increasing order of nearreef water temperature. Larval growth is mean otolith increment width over entire pelagic larval duration (PLD); juvenile growth is mean otolith increment width during the first $4 \mathrm{~d}$ post-emergence. Overall value is the mean for all cohorts

\begin{tabular}{|lccccc|}
\hline Cohort & $\begin{array}{c}\text { Near-reef } \\
\text { temp } \\
\left({ }^{\circ} \mathrm{C}\right)\end{array}$ & $\begin{array}{c}\text { Larval } \\
\text { growth } \\
(\mu \mathrm{m})\end{array}$ & $\begin{array}{c}\text { PLD } \\
(\mathrm{d})\end{array}$ & $\begin{array}{c}\text { Settlement } \\
\text { size } \\
(\mu \mathrm{m})\end{array}$ & $\begin{array}{c}\text { Juvenile } \\
\text { growth } \\
(\mu \mathrm{m})\end{array}$ \\
\hline 10 & 22.8 & 3.6 & 56.0 & 199.1 & 3.9 \\
$\mathrm{C}$ & 23.5 & 4.2 & 49.7 & 190.6 & 6.6 \\
$\mathrm{~A}$ & 24.0 & 4.1 & 52.2 & 199.1 & 5.9 \\
1 & 24.7 & 4.0 & 51.8 & 192.9 & 5.5 \\
7 & 24.8 & 4.3 & 48.2 & 193.6 & 6.8 \\
3 & 26.4 & 4.6 & 46.0 & 196.3 & 6.7 \\
4 & 26.9 & 4.8 & 46.5 & 203.9 & 7.4 \\
$\mathrm{~F}$ & 27.3 & 4.3 & 49.2 & 201.8 & 5.5 \\
$\mathrm{~B}$ & 27.9 & 4.6 & 49.8 & 211.9 & 6.8 \\
6 & 28.4 & 4.8 & 43.9 & 193.2 & 7.4 \\
8 & 28.7 & 5.0 & 39.6 & 183.4 & 6.9 \\
$\mathrm{D}$ & 29.1 & 4.8 & 41.7 & 189.9 & 7.1 \\
E & 29.3 & 4.8 & 41.5 & 189.2 & 6.2 \\
Overall & 26.7 & 4.1 & 47.0 & 195.9 & 6.5 \\
\hline
\end{tabular}

growth (otolith increment width) varied significantly among cohorts at all 3 time periods examined (Days 10, 20, 30; ANOVA $p<0.001$; Fig. 2a). Late-summer cohorts (cohorts B, 6, 8, D and E) exhibited higher larval growth than cohorts recruiting during winter months (cohorts 10 and $C_{i}$ Tukey $\mathrm{p}<0.001$ to 0.006 ) on all 3 test days. Mean increment width varied between the warmest and coolest cohorts by up to $2 \mu \mathrm{m}$ midlarval life, and these growth rate differences led to substantial differences in size-at-age: by Day 40 , otolith radii varied by as much as $50 \mu \mathrm{m}$, or $\sim 25 \%$ (Fig. 2 b).

Mean larval growth (otolith increment width) was directly related to water temperature: seasonal variation in near-reef water temperature accounted for $78 \%$ of the variation in mean overall larval growth (Fig. 3a). When we divided larval life into 3 periods, we observed an even stronger relationship between larval growth and water temperature in the latest period: $\mathrm{r}^{2}=$ 0.89 for Days 21 to 30 (Table 3). Holding the time of set-

Table 3. Thalassoma bifasciatum. $\mathrm{R}^{2}$ values for regressions of mean larval growth $(\mathrm{LG} ; \mu \mathrm{m})$ versus mean water temperature $\left(\mathrm{WT}_{;}{ }^{\circ} \mathrm{C}\right)$, mean pelagic larval duration (PLD; d) versus mean LG and mean WT, and mean juvenile growth during the first $4 \mathrm{~d}$ post-emergence $(\mathrm{JG} ; \mu \mathrm{m})$ versus $\mathrm{LG}$, all measured over the larval period specified. ${ }^{*} \mathrm{p}<0.05,{ }^{* *} \mathrm{p}<0.01,{ }^{* * *} \mathrm{p}<0.001 ;+$ and refer to positive and negative relationships

\begin{tabular}{|c|c|c|c|c|}
\hline Larval growth period & LG vs. WT (+) & PLD vs. LG (-) & PLD vs. WT (-) & JG vs. LG (+) \\
\hline Entire larval period & $0.78^{* * *}$ & $0.85^{* * *}$ & $0.73^{* * *}$ & $0.72^{* * *}$ \\
\hline Increments 1 to 10 & $0.73^{* * *}$ & $0.79^{* * *}$ & $0.62^{* * *}$ & $0.35^{* *}$ \\
\hline Increments 11 to 20 & $0.71^{* * *}$ & $0.85^{* * *}$ & $0.64^{* * *}$ & $0.52^{* *}$ \\
\hline Increments 21 to 30 & $0.89^{* * *}$ & $0.87^{* * *}$ & $0.67^{* * *}$ & $0.44^{* *}$ \\
\hline $2 \mathrm{wk}$ prior to settlement & $0.61^{* *}$ & $0.74^{* * *}$ & $0.74^{* * *}$ & $0.53^{* *}$ \\
\hline $1 \mathrm{wk}$ prior to settlement & $0.49^{* *}$ & $0.74^{* * *}$ & $0.72^{* * *}$ & $0.52^{* *}$ \\
\hline
\end{tabular}




\section{a}
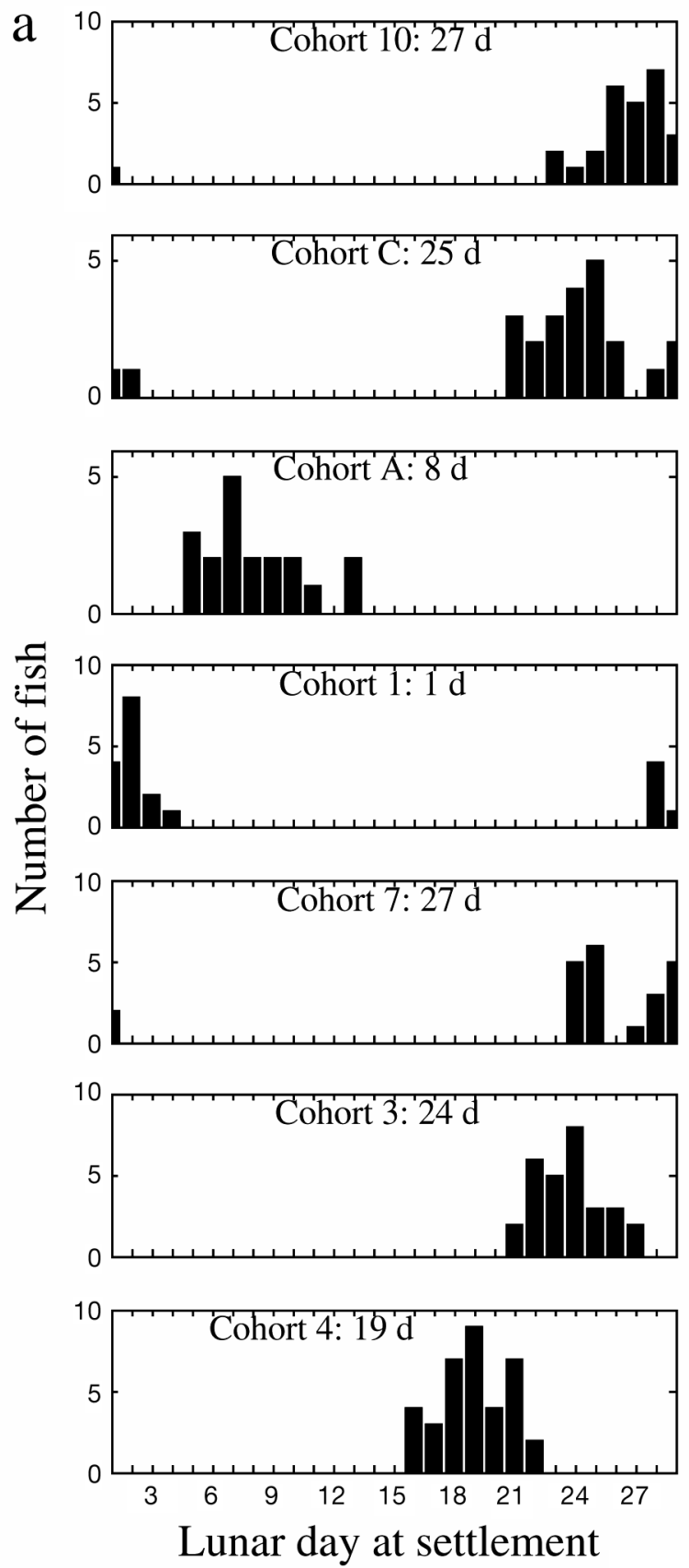

tlement constant for each cohort and back-calculating growth during the previous 1 or 2 wk did not improve the regression between larval growth and water temperature (Table 3). Reduced seasonal fluctuation in FC SST (Fig. 3b) resulted in a slightly weaker relationship between cohort-specific larval otolith growth and the mean FC water temperature $\left(\mathrm{r}^{2}=0.73 ; \mathrm{p}<0.001\right)$.

PLD varied inversely with water temperature over the entire larval period $\left(r^{2}=0.73\right.$; Table 3$)$ and differed significantly among cohorts (ANOVA: $p<0.001$; Table 2). Slow-growing cool-water fish spent longer in the plankton before settling. Variation in mean larval
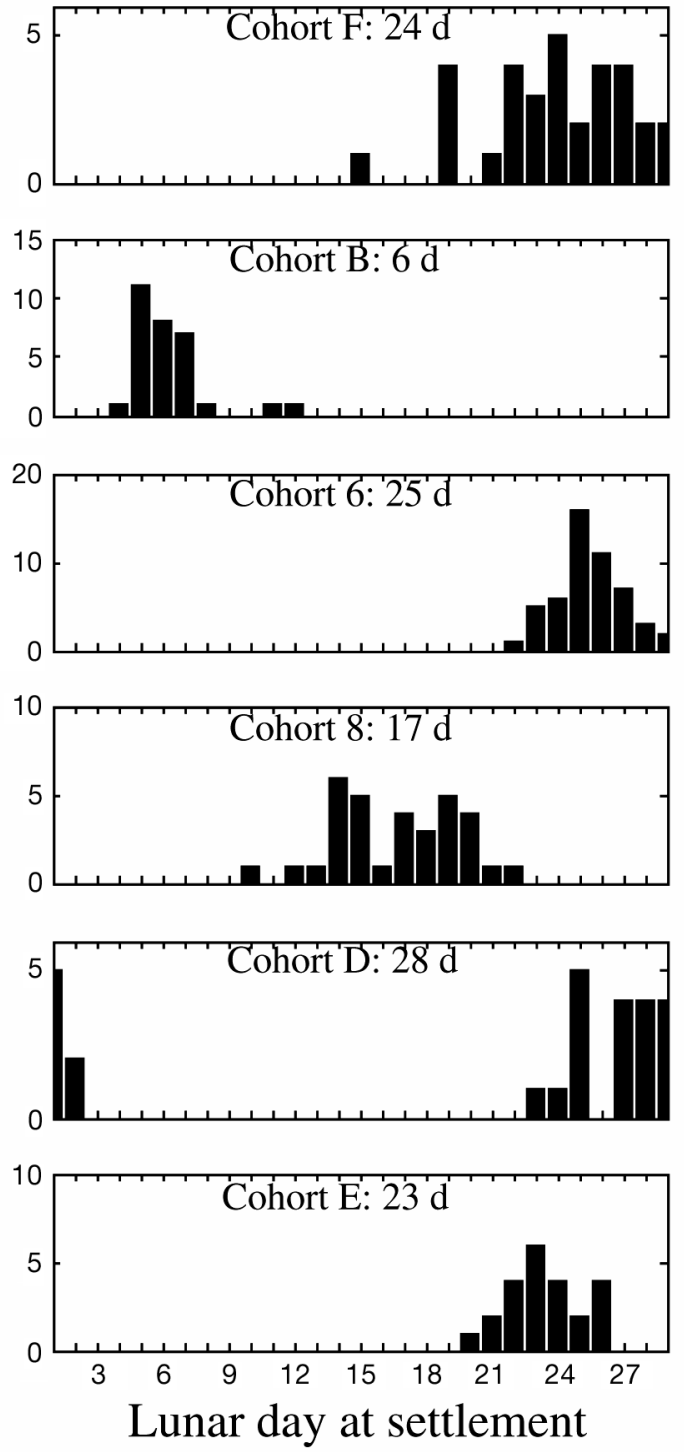

Fig. 1. Thalassoma bifasciatum. Lunar day of (a) settlement and (b) successful spawning for 13 cohorts from the upper Florida Keys (Day 1 = new moon). Where settlement or spawning was non-uniform, the mean day about which settlement/spawning occurred is indicated. Uniform settlement is indicated by NS (not significant)

growth explained $85 \%$ of the variation in PLD (Fig. 4a). Because faster larval growth leads to larger sizes-atage (Fig. 2b) but also to a shorter PLD (fewer days of growth), otolith size-at-settlement (proxy for somatic size-at-settlement) was not directly related to larval growth and could best be described as a quadratic function of PLD ( $\mathrm{r}^{2}=0.47$; $\mathrm{p}<0.05$; Fig. 4b). Rapidlygrowing warm-water larvae (e.g. cohorts 8, D, and E) spent so few days in the plankton that they were the smallest at settlement (Table 2). At intermediate water temperatures, intermediate growers spent more days in the plankton and settled at relatively large sizes. 
b
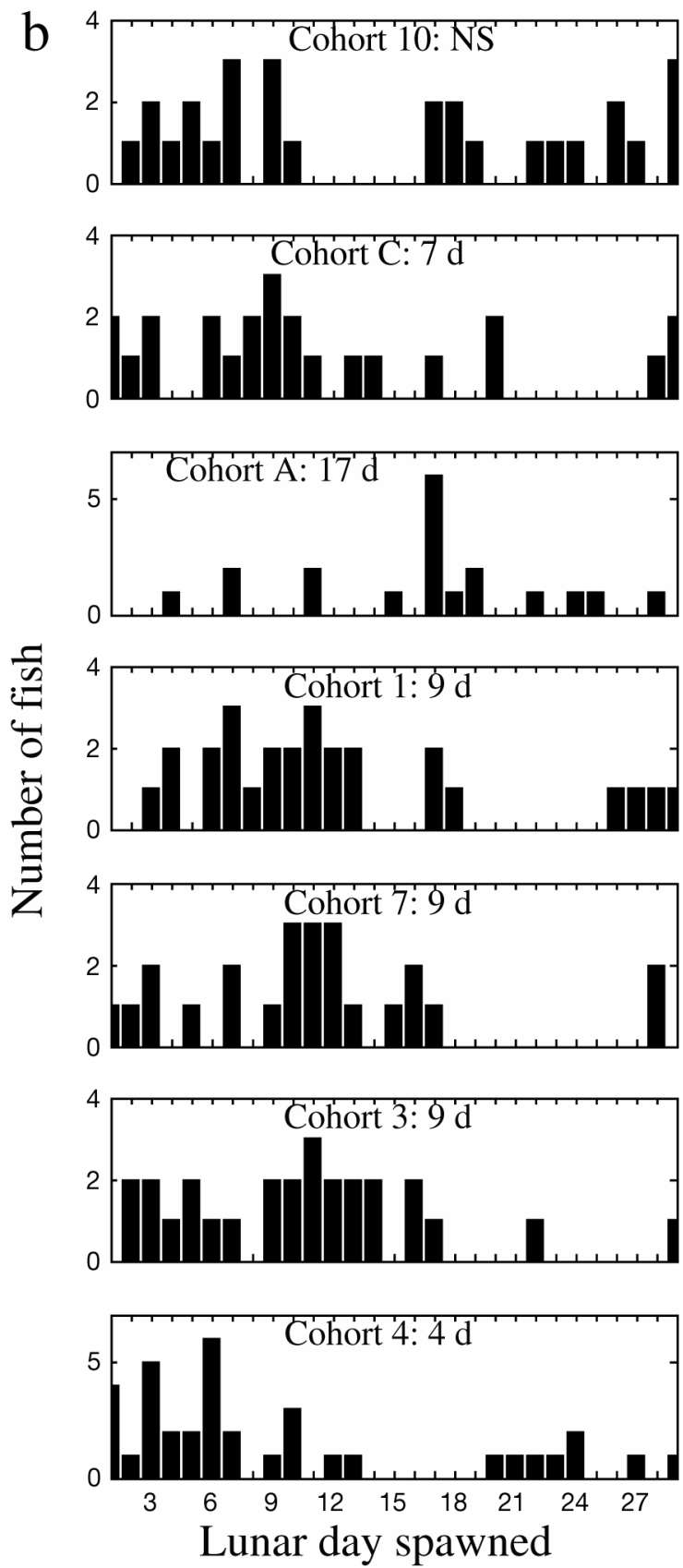

However, in the coolest water temperatures, increased time in the plankton could not offset very low growth rates (e.g. cohorts 10 and C).

Otolith size-at-settlement differed significantly among cohorts (ANOVA p < 0.001), with cohort B significantly larger than cohorts 1, 6, 8, C, D and E, and cohort 8 significantly smaller than cohorts 4,5 and B (Tukey p < 0.001 to 0.04 ). The comparison of relative otolith and somatic size (SL) among the very youngest recruits that grew relatively fast and those that grew more slowly during larval life corroborated that measured differences in otolith radii-at-settlement reflected real
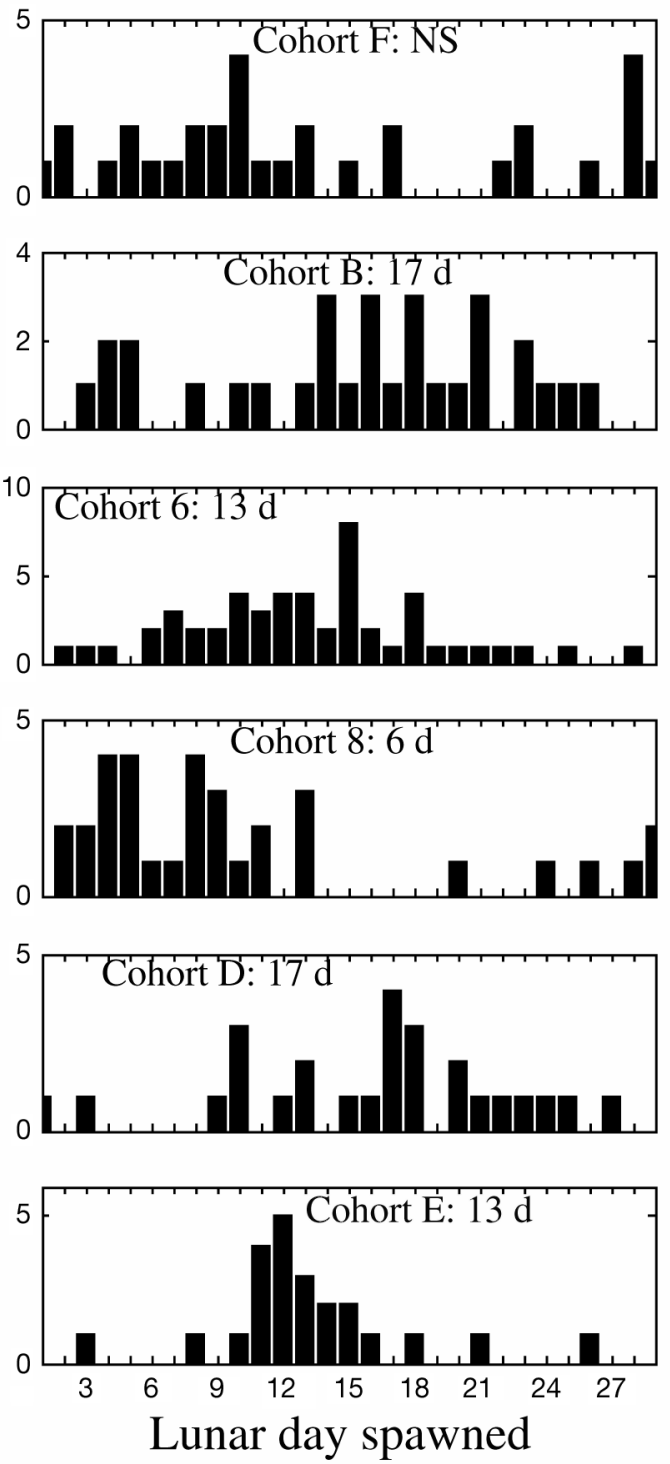

Fig. 1 (continued)

differences in somatic size (Fig. 5). Significantly faster growers $(t$-test $\mathrm{df}=24, \mathrm{p}<0.001)$ with significantly smaller otolith sizes-at-settlement $(t$-test $\mathrm{df}=24, \mathrm{p}<$ $0.001)$ were significantly smaller at emergence than slower growers $(t$-test $\mathrm{df}=24, \mathrm{p}=0.008)$.

Cohort-specific juvenile otolith growth also varied seasonally, with summer and fall cohorts having a mean otolith increment width of $6.9 \mu \mathrm{m}$ and cohort 10 (February 2003) a mean increment width of $3.9 \mu \mathrm{m}$ (Table 2). Variation in juvenile growth during the first $4 \mathrm{~d}$ after emergence onto the reef was directly related to ambient near-reef water temperature during the 
a

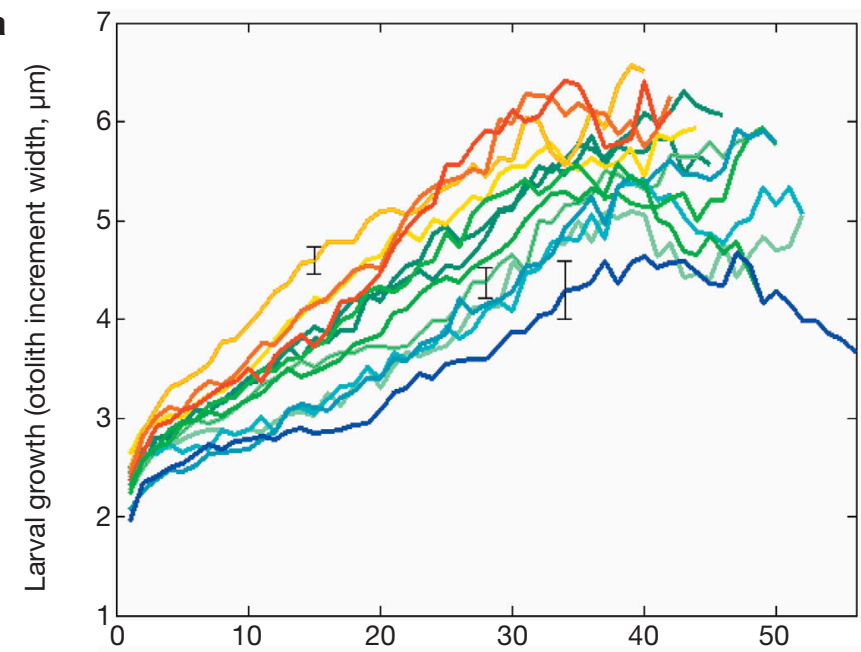

b

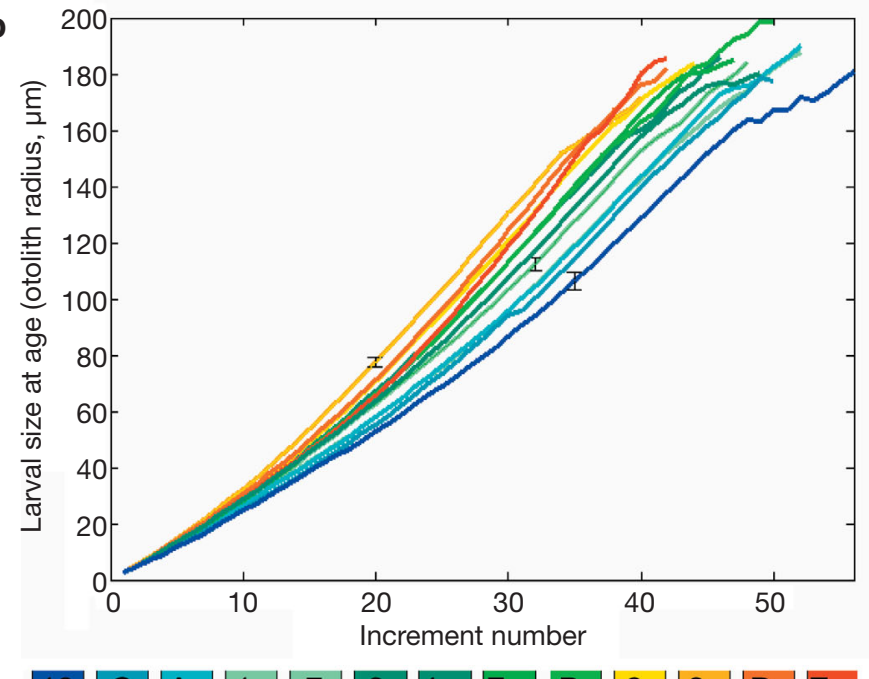

\begin{tabular}{|l|l|l|l||l|l|l|l|l|l||l|l|l|}
\hline 10 & C & A & 1 & 7 & 3 & 4 & $F$ & $B$ & 6 & 8 & $D$ & $E$
\end{tabular}

Fig. 2. Thalassoma bifasciatum. (a) Mean otolith increment widths (proxy for somatic growth) and (b) mean cumulative otolith radius (proxy for size) during the larval period of 13 cohorts from the upper Florida Keys. Trajectories are plotted up to the mean pelagic larval duration for each cohort. Cohorts are identified by color corresponding roughly to the mean near-reef water temperature during the entire larval period of each cohort. Representative SE bars are provided for reference

same period $\left(\mathrm{r}^{2}=0.75\right)$ and, likewise, variation in larval growth $\left(\mathrm{r}^{2}=0.78\right)$ (Fig. 6a, Table 3$)$.

Differences in juvenile growth contributed to some shifting in relative size-at-post-emergence-age during early juvenile life for the cohorts that were in the warmest and coolest water as larvae. Although warmwater cohorts were generally the smallest at settlement, faster early juvenile growth enabled them to increase in juvenile size-at-age to more intermediate values by Day 4 (Fig. 6b). Similarly, cool-water cohorts that were intermediate in size-at-settlement continued to grow slowly and dropped to the lower end of the juvenile
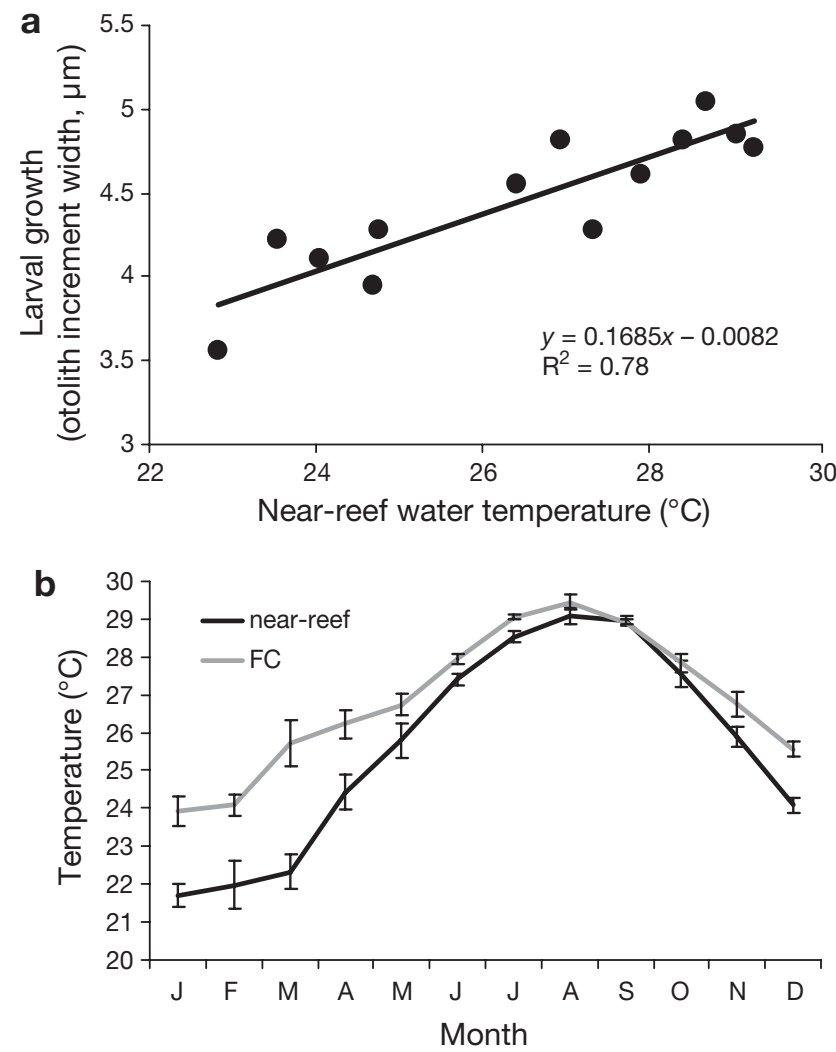

Fig. 3. Thalassoma bifasciatum. (a) Relationship between mean otolith increment and near-reef water temperature during the entire larval period for 13 cohorts. (b) Mean water temperature $( \pm$ SE) off the upper Florida Keys during 2000 to 2003. Near-reef temperature was measured at $21 \mathrm{~m}$ depth at Conch Reef; Florida Current (FC) temperature was estimated from SST satellite imagery at a point offshore of the study sites

size-at-age range by Day 4. Cohorts that were in intermediate water temperatures as larvae (e.g. cohort 4 and B) were in relatively warm water as juveniles; thus, fast growth enabled these cohorts to maintain their larger sizes at settlement during the first $4 \mathrm{~d}$ of juvenile life (e.g. at Day 4 cohorts 4 and B were significantly larger than cool water cohorts 10,1, and 7 as well as warmwater cohort 8 ; B was also larger than $\mathrm{C}$ and $\mathrm{E}_{\text {; }}$ ANOVA $\mathrm{p}<0.001$; Tukey $\mathrm{p}<0.001$ to 0.05 ; Fig. $6 \mathrm{~b}$ ).

The size of recruitment events was relatively small: density varied between 0.13 to 0.45 recruits $\mathrm{m}^{-2}$ with an overall mean of 0.26 recruits $\mathrm{m}^{-2}$. There were no clear seasonal patterns-the largest event in 2000 occurred during August, but during 2001 the large events occurred in October and December. There were no significant relationships between the magnitude of recruitment events (i.e. cohort density) and any early life history trait. Neither was recruitment related to ambient water temperature during larval life (leastsquares linear regression: $p=0.34$ ). Levels of recruitment were consistently low for cool-water cohorts, but 

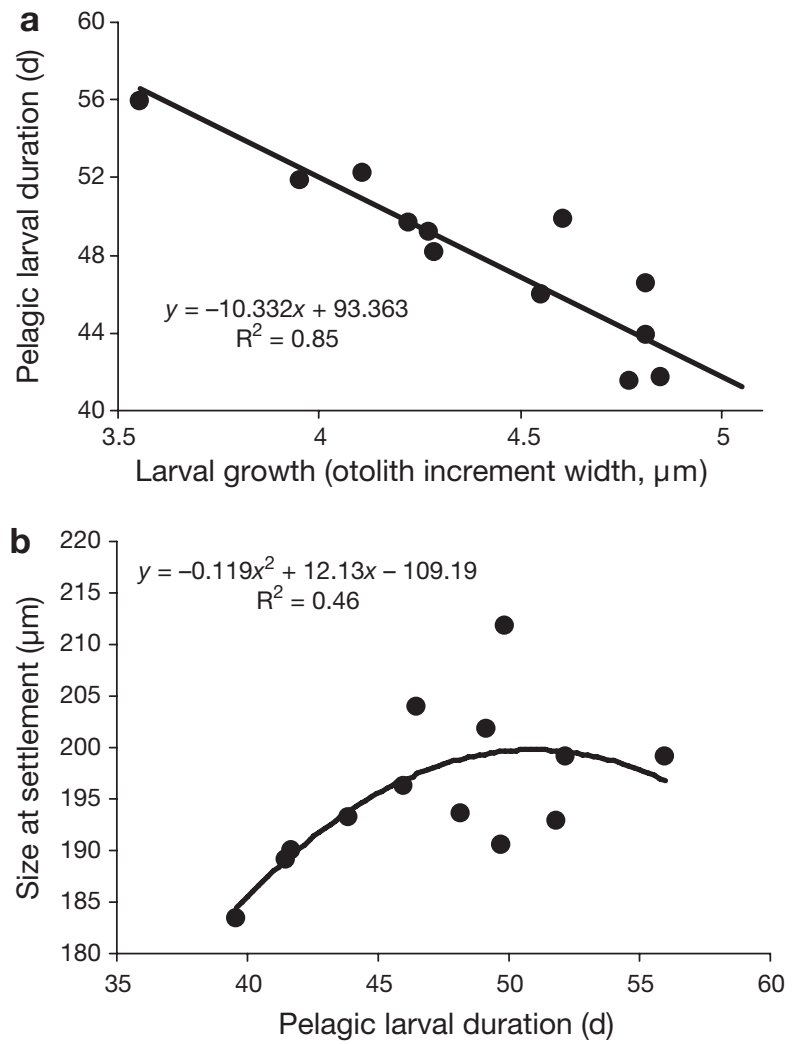

Fig. 4. Thalassoma bifasciatum. Relationship between (a) mean pelagic larval duration (PLD) and larval growth (mean otolith increment width over entire larval period), and (b) mean sizeat-settlement and PLD for 13 cohorts that recruited to the upper Florida Keys. Linear regressions were fit to data using least squares techniques; however, for (b) a polynomial regression provided a better fit

quite variable for warm-water cohorts (recruitment beyond $28.5^{\circ} \mathrm{C}$ was also generally low). If 4 cohorts that settled during or shortly after the nearshore passage of a mesoscale eddy were removed from the analysis (e.g. cohorts 1, 8, D, and $\mathrm{E}_{\text {; }}$ Table 4), variation in water temperature explained $61 \%$ of the variability in recruitment magnitude (Fig. 7).

\section{DISCUSSION}

Recent studies have begun to demonstrate that, similar to temperate species (Houde 1987, Meekan \& Fortier 1996, Hare \& Cowen 1997, Shima \& Findlay 2002), variation in the growth of larvae of tropical fishes may have important consequences for their survival (Searcy \& Sponaugle 2001, Vigliola \& Meekan 2002, Wilson \& Meekan 2002, Hoey \& McCormick 2004, McCormick \& Hoey 2004) and thus, potentially, the magnitude of larval supply and juvenile recruitment (Bergenius et al. 2002, Wilson \& Meekan 2002). However, we

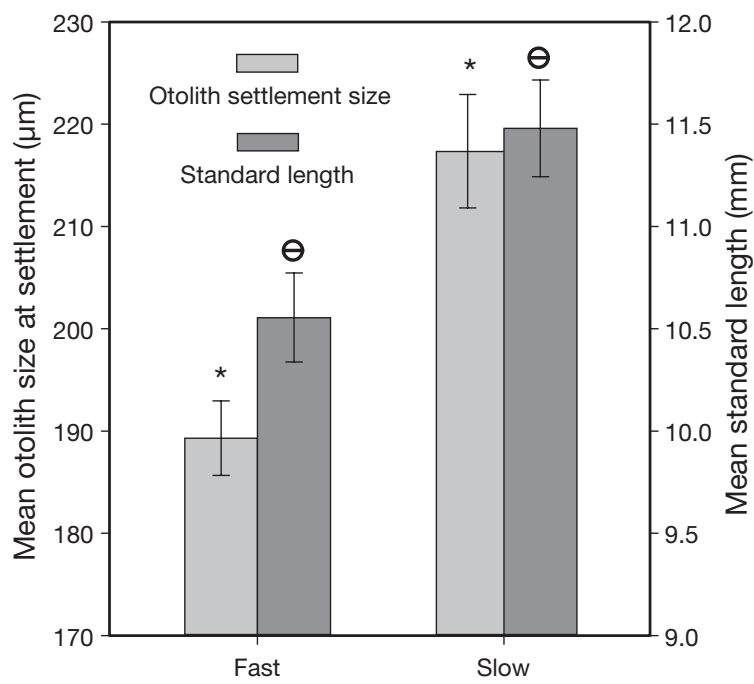

Fig. 5. Thalassoma bifasciatum. Mean otolith size (radius)-atsettlement and standard length (SL) of new recruits (i.e. 0 to $1 \mathrm{~d}$ old post emergence) to the upper Florida Keys that grew relatively fast as larvae (mean increment width $=4.3 \mu \mathrm{m}$, pelagic larval duration $[\mathrm{PLD}]=39$ to $45 \mathrm{~d}, \mathrm{n}=14$ ) versus those that grew more slowly (mean increment width $=3.8 \mu \mathrm{m}$, $\mathrm{PLD}=50$ to $69 \mathrm{~d}, \mathrm{n}=12$ ). Error bars $=\mathrm{SE},{ }^{*} \mathrm{p}<0.001, \theta: \mathrm{p}<0.01$

are still at the early stages of identifying and defining such variability within tropical species and understanding the processes that contribute to this variability.

\section{Larval growth variability and water temperature}

Thalassoma bifasciatum recruits year-round to the upper Florida Keys, but the early life history traits of cohorts settling during different seasons are highly variable. Variation in near-reef water temperatures explained $78 \%$ of the variation in larval otolith growth exhibited by 13 cohorts settling over several years: larval growth of winter cohorts was significantly lower than larval growth of late-summer cohorts. Almost $90 \%$ of the variation in growth during $10 \mathrm{~d}$ in the middle of the larval period (Days 21 to 30) was due to differences in water temperature.

The strong dependency of larval growth on temperature is consistent with many previous studies of temperate marine, estuarine, and freshwater larvae, both within species and across a variety of species (Houde 1989, Pepin 1991, Blaxter 1992, Houde \& Zastrow 1993, Rombough 1997, Benoît et al. 2000). Tropical coral reef fishes have lower larval growth rates than would be predicted by temperature (Houde \& Zastrow 1993) and, in general, are thought to be less responsive to changes in water temperature (Rombough 1997). However, Houde \& Zastrow (1993) suggested that small differences in water temperature in the Indo- 

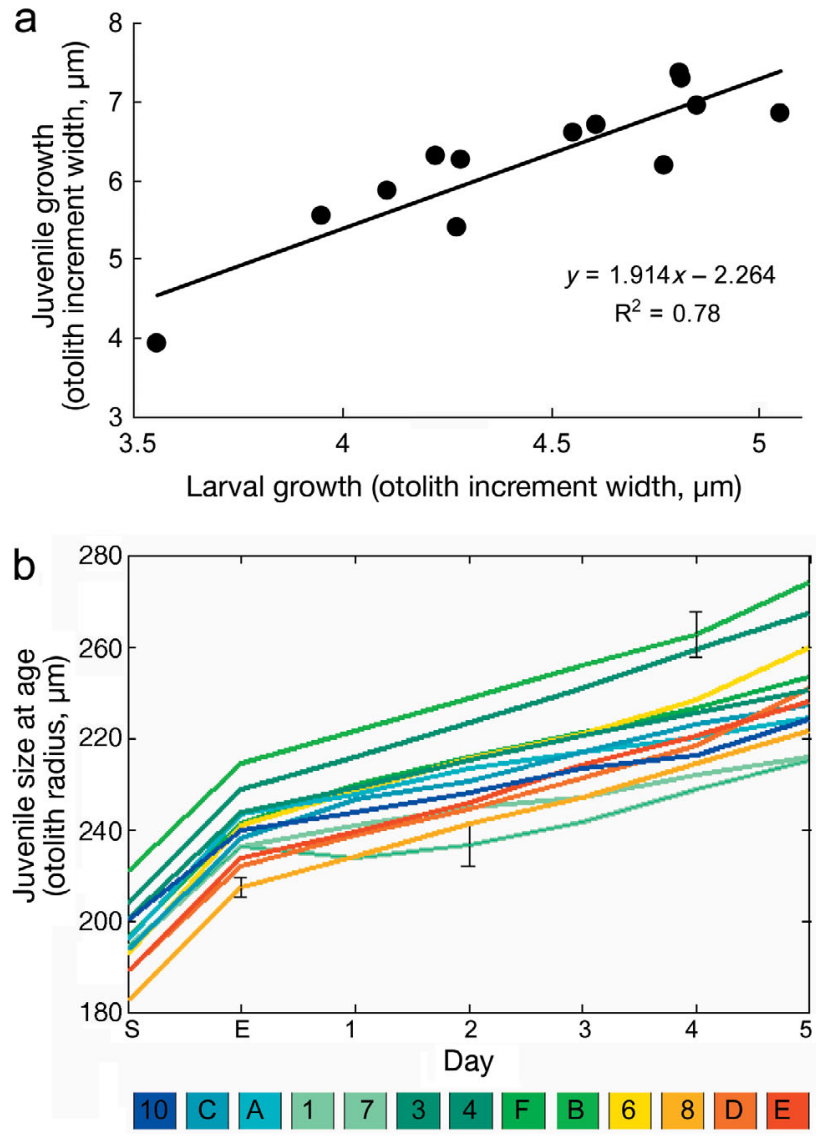

Fig. 6. Thalassoma bifasciatum. (a) Relationship between mean juvenile growth (mean otolith increment width) during the first $4 \mathrm{~d}$ on the reef and larval growth (mean otolith increment width) during the entire larval period for 13 cohorts that recruited to the upper Florida Keys. (b) Juvenile size (mean cumulative otolith radius) at settlement (S), emergence onto the reef (E), and the first $4 \mathrm{~d}$ on the reef. Statistical comparisons were made using Day 4 values due to sample size limitations. Sample SE bars are provided for reference. Cohorts are identified by color corresponding roughly to the mean near-reef water temperature during the entire larval period of cohort

Pacific and Caribbean may account for observed geographic differences in PLD for some fishes. Indeed, evidence is beginning to accumulate for a diversity of tropical reef fishes that fluctuations in water temperature can explain some of the variability in early life history traits.

A compilation of $\mathrm{Q}_{10}$ data suggests that temperate and tropical species respond in similar ways to temperature changes (Green \& Fisher 2004). Of course, the influence of water temperature is much less apparent where there is little variation in water temperature. Growth of larval Acanthurus chirugus settling to Panamanian reefs over $3.5 \mathrm{yr}$ was unrelated to water temperature (Bergenius et al. 2005). Similarly, variation in water temperature did not influence the growth of Thalassoma bifasciatum settling to Barbados during spring and fall months (Searcy \& Sponaugle 2000). In both cases, the authors point to the lack of substantial seasonal water temperature fluctuation as contributing to the reduced role of temperature variation in influencing larval growth. However, evidence from other species indicates that water temperature can influence larval growth of tropical reef fishes. A combination of temperature, rainfall, and wind explained 7 to $36 \%$ of the variation in larval growth of the bicolor damselfish Stegastes partitus in Panama (Wilson \& Meekan 2002). Elsewhere, ambient water temperature explained $30 \%$ of the variation in larval growth rates of the goatfish Upeneus tragula (McCormick \& Molony 1995) and the damselfish Pomacentrus coelestis (Meekan et al. 2003). We found that water temperature had an even stronger effect on larval growth in Thalassoma bifasciatum in the Florida Keys (explaining 78 to $89 \%$ of growth variation), leaving little room for improvement by the addition of other factors. The $6^{\circ} \mathrm{C}$ variation in water temperature among cohorts likely contributed to the strong influence of temperature on larval growth as well as our ability to detect it.

Larval growth efficiency does not differ between temperate and tropical waters, therefore temperaturemediated metabolic rates require that relatively high food supplies be available for larvae growing in warm waters (Houde 1989). For example, time to starvation for several unfed fish species under laboratory conditions was shorter for fish reared at higher water temperatures (Houde 1974, Fukuhara 1990). In addition, the rapid depletion of nutrients in warm tropical waters with stable water columns (e.g. Gonzalez et al. 2000) may result in lower larval food availability. Thus, warm water cohorts should have the highest risk of food limitation or starvation at any point during larval life. Although we did not observe any indirect effects of reduced food availability on growth, such as reduced growth rates at higher temperatures, it is possible that several of the warmest water cohorts were directly affected by food limitation and had higher mortality rates (these larvae would not have been represented in our samples of juveniles that successfully settled). Higher larval mortality rates may have contributed to smaller than predicted recruitment events for some of these warm-water cohorts (see below).

\section{Larval duration and size at settlement}

As a result of the distinct temperature-related variation in larval growth, mean cohort-specific PLD also varied with temperature and larval growth: variation in mean larval growth explained $85 \%$ of the variability 
Table 4. Thalassoma bifasciatum. Settlement (settle) windows and passage of mesoscale eddies (ME) by cohort, listed in chronological order. Dates of mesoscale eddy passage were determined by analysis of current meter records and satellite imagery in conjunction with other studies. - indicates that no mesoscale eddies passed by the study site

\begin{tabular}{|lcccl|}
\hline Cohort & $\begin{array}{c}\text { Earliest } \\
\text { settle date } \\
(\mathrm{mo} / \mathrm{d} / \mathrm{yr})\end{array}$ & $\begin{array}{c}\text { Latest } \\
\text { settle date } \\
(\mathrm{mo} / \mathrm{d} / \mathrm{yr})\end{array}$ & $\begin{array}{c}\text { Mesoscale } \\
\text { eddy passage } \\
(\mathrm{mo} / \mathrm{d} / \mathrm{yr})\end{array}$ & Source \\
\hline $\mathrm{A}$ & $4 / 8 / 00$ & $4 / 16 / 00$ & - & Ocean color imagery \\
1 & $5 / 1 / 00$ & $5 / 7 / 00$ & $4 / 21 / 00-5 / 4 / 00$ & Ocean color imagery \\
3 & $6 / 22 / 00$ & $6 / 28 / 00$ & - & Sponaugle et al. (2003) \\
4 & $7 / 16 / 00$ & $7 / 22 / 00$ & - & Sponaugle et al. (2003) \\
$\mathrm{B}$ & $8 / 3 / 00$ & $8 / 11 / 00$ & - & Sponaugle et al. (2003) \\
6 & $8 / 21 / 00$ & $8 / 28 / 00$ & - & Sponaugle et al. (2003) \\
$\mathrm{C}$ & $4 / 14 / 01$ & $4 / 22 / 01$ & - & Ocean color imagery \\
7 & $5 / 16 / 01$ & $5 / 23 / 01$ & - & Sponaugle et al. (2005) \\
8 & $8 / 1 / 01$ & $8 / 8 / 01$ & $7 / 18 / 01-7 / 27 / 01$ (ME2) & Sponaugle et al. (2005) \\
$\mathrm{D}$ & $9 / 10 / 01$ & $9 / 18 / 01$ & $9 / 13 / 01-10 / 01$ (ME3) & Sponaugle et al. (2005) \\
$\mathrm{E}$ & $9 / 26 / 02$ & $10 / 2 / 02$ & $9 / 18 / 02-9 / 29 / 02$ (ME3) & $\begin{array}{l}\text { D'Alessandro (2005) } \\
\mathrm{F}\end{array}$ \\
$11 / 24 / 02$ & $12 / 2 / 02$ & - & D'Alessandro (2005) \\
10 & $1 / 24 / 03$ & $2 / 1 / 03$ & - & Ocean color imagery \\
\hline
\end{tabular}

Larval growth and PLD both influenced size-at-settlement: the positive relationship between larval growth and otolith size and the inverse relationship between larval growth and PLD resulted in a curvilinear relationship between mean otolith size-at-settlement (proxy for settlement size) and PLD. Faster growing larvae were larger-at-age during the larval period, but because they spent fewer days in the plankton, they were generally smaller at settlement (see also Searcy \& Sponaugle 2000). However, cohorts with the longest mean PLD were growing so slowly that even though they spent up to $16 \mathrm{~d}$ longer in the plankton, their otolith size-at-settlement was not as large as would be expected based on PLD alone. A com-

in PLD. An inverse relationship between larval growth and PLD was identified by Houde $(1987,1989)$ among a diversity of temperate and tropical marine fish. This has been further demonstrated empirically within species in a number of laboratory studies of tropical fishes. Slower-growing damselfish (Green \& Fisher 2004, Green \& McCormick 2005) and goatfish (McCormick \& Molony 1995) larvae raised at $25^{\circ} \mathrm{C}$ took longer to undergo metamorphosis than larvae reared at higher temperatures. Consistent results have also been found in field studies. Faster-growing larvae both within and among cohorts of Thalassoma bifasciatum recruiting to Barbados had shorter PLDs (Searcy \& Sponaugle 2000, Sponaugle \& Pinkard 2004a).

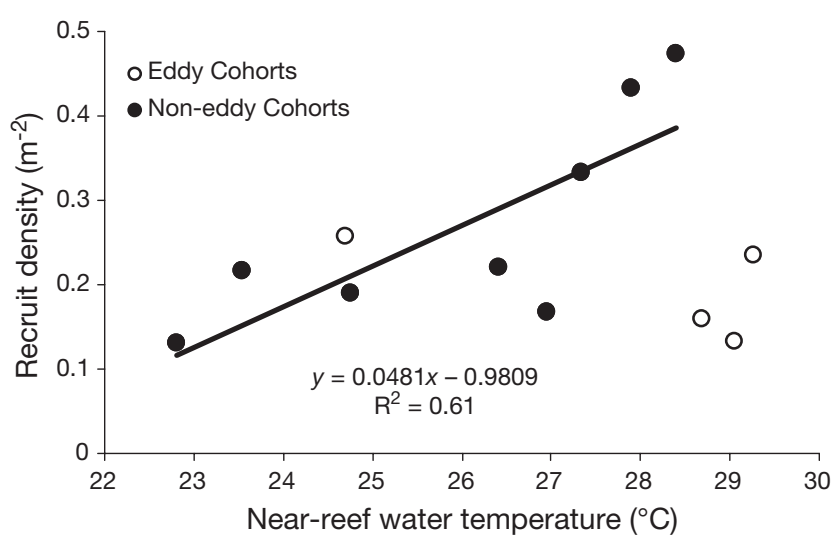

Fig. 7. Thalassoma bifasciatum. Mean cohort-specific recruit density as a function of mean water temperature experienced during larval life. Least squares regression of all cohorts was not significant, but exclusion of 4 cohorts that settled during the passage of mesoscale Florida Current frontal eddies (O: eddy cohorts) resulted in a significant relationship (regression line) between temperature and magnitude of recruitment for the remaining cohorts parison of somatic size of the youngest recruits confirmed these otolith relationships. Larvae in intermediate water temperatures were consistently larger at settlement than larvae in either cooler or warmer water. Fuiman et al. (1998) concluded that in response to changing temperatures, developmental rate changes more than growth such that larvae experiencing different temperatures are different sizes at metamorphosis. Clearly, with a variable age- and size-at-settlement, competency to settle does not appear to be directly age- or size-based in Thalassoma bifasciatum. Searcy \& Sponaugle (2000) suggested that competency to settle in $T$. bifasciatum may be determined by attaining a minimum condition (more rapid in fast-growing individuals).

\section{Influence of water temperature on recruitment}

As a result of the inverse relationship between larval growth and PLD, fast-growing Thalassoma bifasciatum larvae were not only larger-at-age in the plankton but had the advantage of a shorter stage duration. The size advantage, growth rate, and stage duration hypotheses (Anderson 1988) would all predict that these fastgrowing cohorts should experience higher survival. By extension and with all else being equal (e.g. spawning output), larvae from these cohorts should settle in the highest numbers. While it is true that the highest recruitment rates were exhibited by warm water cohorts, there was substantial variance in recruitment magnitude among the warmest water cohorts. Cool water cohorts settled in consistently small events, whereas warm water cohorts settled in both large and small events. Thus, regressions of cohort density 
versus cohort-specific water temperature and early life history traits were not significant.

We focus on 2 primary explanations for this observation. The first, as suggested earlier, is that larvae may have increased difficulty in sustaining higher growth rates in warm water due to food limitation, which would result in higher mortality for some fast-growing warm water cohorts. Such constraints may establish a threshold temperature (e.g. $28.5^{\circ} \mathrm{C}$ ), beyond which recruitment is more variable and frequently low. Comparisons among a diversity of fishes have shown that larval mortality varies directly with water temperature (Houde 1989, Pepin 1991). Although such relationships should not be extended to patterns within individual species (Houde 1989), Pepin (1991) suggests that higher mortality rates at higher water temperatures may counter the positive advantages of higher growth and shorter stage duration. Higher risk of successfully sustaining fast growth would be consistent with our observations of more variance in recruitment at higher temperatures.

The second potential explanation for the lack of a strong relationship between recruitment and larval growth or water temperature is through the interaction of physical oceanography. When the cohorts that settled during or immediately following the nearshore passage of a mesoscale eddy were omitted from the analysis (the complexity of eddy passage prevented the simple quantification or incorporation into a regression relationship), variation in water temperature explained $61 \%$ of the variation in recruitment strength. The reefs of the Florida Keys are uniquely situated at the frontal boundary between a shallow coastal system and a strong western boundary current. Consistent in strength, the FC is less consistent in position, meandering on and offshore as eddies of various sizes propagate along the front (Lee \& Williams 1999). Many reef fish larvae may remain in nearshore waters directly over the reef during their larval period (Sponaugle et al. 2003), while others may be transported to the reef via the passage and nearshore impingement of mesoscale eddies (Sponaugle et al. 2005). Depending on the specifics of the timing and movement of such features, frontal eddies also have the potential to advect larvae out of the system, resulting in smaller than expected settlement events (D'Alessandro 2005). Thus, the nearshore passage of eddies along the Florida Keys may decouple the relationship between water temperature, larval growth, and recruitment.

Bergenius et al. (2005) recommended that multiple variables be considered when seeking to explain settlement or recruitment variability. Indeed, combinations of a number of environmental variables were needed to explain $22 \%$ of year-round recruitment variability of Acanthurus chirurgus (40\% within a season).
The examination of multiple variables has been somewhat less successful in explaining Thalassoma bifasciatum recruitment to 2 other Caribbean locations. In Panama, Wilson \& Meekan (2001) found no relationship over 18 mo between the magnitude of $T$. bifasciatum settlement events and wind speed and direction, rainfall, solar radiation, or water temperature. Similarly, monthly $T$. bifasciatum recruitment over $11 \mathrm{yr}$ was unrelated to wind or tides (Robertson et al. 1999). In Barbados, although the growth of larval T. bifasciatum was reduced during the passage of low salinity North Brazil Current rings by the island, settlement magnitude was not consistently lower following ring passage and in one prominent case was substantially enhanced (Sponaugle \& Pinkard 2004a). These patterns were thought to be the result of the interaction of both growth-rate and transport-related processes. In the present study, temperature variation alone explained more than $60 \%$ of the variability in recruitment after cohorts experiencing major adjective processes were removed. It should be noted, however, that although the strong positive relationship between larval growth and water temperature indicates that growth-related mechanisms are important during larval life, water temperature also likely influences adults, and thus potentially spawning output.

The influence of growth-rate processes on recruitment strength is likely species- and location-specific. Growth-rate processes accounted for a significant amount of monthly variability in light trap catches of the damselfishes Stegastes partitus (Wilson \& Meekan 2002) and Pomacentrus coelestis (Meekan et al. 2003), and growth during a $4 \mathrm{~d}$ window early in larval life explained $49 \%$ of the variability in the settlement of an acanthurid (Bergenius et al. 2002). The relative importance of water temperature in influencing recruitment strength (via growth) will probably vary not only geographically, depending on the seasonal range in water temperature experienced by larvae, but also depending on the physical setting of different locations. Growth-related processes will likely play a greater role in influencing settlement in physically benign locations, whereas transport-related processes may overwhelm growth-rate processes in oceanographically dynamic areas. In the Florida Keys, water temperature is an important influence on recruitment but this signal may sometimes be obscured by mesoscale advection events.

\section{Timing of spawning and settlement}

Patterns of back-calculated spawning (i.e. 'successful spawning', sensu Sponaugle \& Pinkard 2004b; or 'settler production', sensu Robertson et al. 1999) and 
settlement of Thalassoma bifasciatum in the Florida Keys were generally similar to patterns elsewhere in the Caribbean. Lunar spawning patterns of most cohorts were more variable than the settlement records and occurred during the first quarter to full moon periods ( Days 7 to 15), whereas settlement was generally concentrated between the third quarter and new moon periods ( Days 21 to 1 ). With a maximum mean PLD difference of $16 \mathrm{~d}$ among cohorts of $T$. bifasciatum, some shifting in the time of either spawning or settlement must occur between warm versus cooler water cohorts. Eight of the 13 cohorts exhibited this general pattern (although spawning of 2 of these cohorts, 10 and $F$, was not significantly concentrated in any one period).

The remaining cohorts included fish that settled during eddy and non-eddy periods: mean spawning of both cohorts A and B was several days late; thus, after slightly longer PLDs, they also settled later than the 'general' pattern. Cohort 4 displayed the opposite pattern: fish were spawned slightly earlier and after a mean PLD, settled a few days early. Cohorts 8 and D (both with short PLDs) exhibited 2 quite different patterns. Spawning of cohort 8 fell within the general pattern, but these fish with the shortest PLD exhibited the earliest settlement. In contrast, fish from cohort D were spawned a few days late (similar to cohorts A and B) but a short PLD enabled them to settle within the general window, rather than late like A and B. Thus, there was no consistent trend in how the relative timing of spawning and settlement was shifted with changes in PLD. A flexible PLD may enable larvae to synchronize settlement to optimal settlement periods (Sponaugle \& Cowen 1994, Robertson et al. 1999), and larvae settling during non-optimal periods may need to be of higher condition to survive (Sponaugle \& Pinkard 2004b). Because so few cohorts settled to the Florida Keys outside of the general or 'optimal' settlement pattern (only cohorts A and B settled during the first quarter moon), we did not have sufficient data to examine this in greater detail.

\section{Larval-juvenile stage linkages}

Fast-growing larval Thalassoma bifasciatum cohorts with shorter PLDs settled at smaller sizes. According to the size-advantage hypothesis (i.e. 'bigger-is-better'; Anderson 1988, Sogard 1997), this may suddenly place new settlers at a survival disadvantage. Interestingly, due to the warm water temperatures encountered by these settlers on the reef, new warm-water recruits grew at faster juvenile growth rates. Within the first $4 \mathrm{~d}$ on the reef they were able to reach or even exceed the size-at-age of larger, cool-water settlers. This is not 'growth compensation' per se because this high juvenile growth rate does not follow a period of reduced growth (Sogard \& Olla 2002). However, warmer water temperatures enable a form of size compensation, enabling fast-growing but small settlers to rapidly increase their relative size. Fishes settling at intermediate temperatures were the largest, and relatively rapid juvenile growth enabled them to maintain this pattern over the first $4 \mathrm{~d}$ on the reef.

\section{Growth-rate processes, recruitment, and population connectivity}

Variation in water temperature significantly influences several critical early life history traits of Thalassoma bifasciatum recruiting to the Florida Keys, and accounts for a significant portion of the variability in recruitment strength. Such variation or plasticity in early life history traits, particularly in PLD, also has the potential to influence the distance traveled by larvae and, thereby, ecological connectivity among local populations. Larvae experiencing a difference in mean water temperature of $6^{\circ} \mathrm{C}$ had PLDs that differed by as much as 16 days. In addition to the effect on larval survivorship, less time in the plankton may theoretically contribute to reduced dispersal and higher selfrecruitment (Sponaugle et al. 2002). By extension, it is therefore possible that ecological connectivity is lower in regions experiencing generally warmer water temperatures or during warm seasons. Further, the dependence of fast-growing warm-water larvae on high food resources could reduce the ability of larvae to survive transit through nutrient-poor oceanic waters, further decreasing the likelihood of successful long-distance transport through warm water (although vertical migration among different thermal layers of the water column may be one mechanism that enables larvae to balance growth and access to food in different water masses).

The tighter relationship between larval growth of Thalassoma bifasciatum and near-reef versus FC water temperatures is consistent with near-reef residency of larvae, even during the cool winter months. The greater variance between on- and offshore winter water temperatures may underlie this difference, but it is important to note that there is also likely more error associated with estimating SST from satellite imagery. Detailed ichthyoplankton studies examining the growth and relative condition of reef fish larvae both near-reef and farther offshore will contribute to our ability to resolve such questions. In addition, the inclusion of empirical data on the relationships between larval growth, PLD, and water temperature (as well as other variables such as temperature-dependent mor- 
tality rates [Houde 1989] and, in some cases, temperature-mediated spawning [Danilowicz 1995]) together with remotely-sensed water temperatures in numerical dispersal models should enable refinement of our understanding of the conditions influencing population connectivity in marine organisms.

Acknowledgements. This project was supported by NSF Grant No. OCE-9986359 to S.S. We thank many individuals who participated in the fish censuses and collections as divers and boat tenders: J. Fortuna, M. Paddack, K. Denit, M. Sullivan, C. Paris, E. D'Alessandro, D. Richardson, C. Dickman, A. Mass, and R. Fortuna. Fish were collected under permits \#00S-524 and 02R-524 from the Florida Fish and Wildlife Conservation Commission, and permits \#2001-004 and 2002-025A from the Florida Keys National Marine Sanctuary. All collection and fish handling procedures were approved under the UM Animal Care and Use Permit \#01-056. Early collections were made from a small vessel provided by the Institute of Marine Science. Later sampling was made possible by a vessel provided through Maytag Chair Endowment funds and the EPA-funded National Caribbean Coral Reef Research Center. T. Boone and L. Matragrano helped dissect fishes from some of the cohorts. Water temperature data were provided by S. Miller from the National Undersea Research Center. SST images were provided by D. Olson, RSMAS. Ocean color images were provided by F. Müller-Karger at University of South Florida. The manuscript benefited from the comments of R.K. Cowen, J. Llopiz, D. Richardson, M. McCormick, and 2 anonymous reviewers.

\section{LITERATURE CITED}

Anderson JT (1988) A review of size dependent survival during pre-recruit stages of fishes in relation to recruitment. J Northwest Atl Fish Sci 8:55-66

Batschelet E (1981) Circular statistics in biology. Academic Press, New York

Benoît HP, Pepin P, Brown JA (2000) Patterns of metamorphic age and length in marine fishes, from individuals to taxa. Can J Fish Aquat Sci 57:856-869

Bergenius MAJ, Meekan MG, Robertson DR, McCormick MI (2002) Larval growth predicts the recruitment success of a coral reef fish. Oecologia 131:521-525

Bergenius MAJ, McCormick MI, Meekan MG, Robertson DR (2005) Environmental influences on larval duration, growth and magnitude of settlement of a coral reef fish. Mar Biol 147:291-300

Blaxter JHS (1992) The effect of temperature on larval fishes. Neth J Zool 42:336-357

Campana SE (1996) Year-class strength and growth rate in young Atlantic cod Gadus morhua. Mar Ecol Prog Ser 135: $21-26$

Chambers RC, Leggett WC (1987) Size and age at metamorphosis in marine fishes: an analysis of laboratory-reared winter flounder (Pseudopleuronectes americanus) with a review of variation in other species. Can J Fish Aquat Sci 44:1936-1947

Cowen RK (2002) Larval dispersal and retention and consequences for population connectivity. In: Sale PF (ed) Coral reef fishes: dynamics and diversity in a complex ecosystem. Academic Press, London, p149-170

Cowen RK, Sponaugle S (1997) Relationships between early life history traits and recruitment among coral reef fishes.
In: Chambers RCF, Trippel EA (eds) Early life history and recruitment in fish populations. Chapman \& Hall, London, p 423-449

D'Alessandro E (2005) Patterns and processes of larval fish supply to the coral reefs of the Florida Keys. MS thesis, University of Miami

Danilowicz BS (1995) The role of temperature in spawning of the damselfish Dascyllus albisella. Bull Mar Sci 57: 624-636

Fuiman LA, Poling KR, Higgs DM (1998) Quantifying developmental progress from comparative studies of larval fishes. Copeia 1998:602-611

Fukuhara O (1990) Effects of temperature on yolk utilization, initial growth, and behaviour of unfed marine fish-larvae. Mar Biol 106:169-174

González N, Müller-Karger FE, Estrada SC, de los Reyes RP, del Río IV, Pérez PC, Arenal IM (2000) Near-surface phytoplankton distribution in the western Intra-America Sea: the influence of El Niño and weather events. J Geophys Res 105:14029-14043

Green BS, Fisher R (2004) Temperature influences swimming speed, growth and larval duration in coral reef fish larvae. J Exp Mar Biol Ecol 299:115-132

Green BS, McCormick MI (2005) Maternal and paternal effects determine size, growth and performance in larvae of a tropical reef fish. Mar Ecol Prog Ser 289:263-272

Hare JA, Cowen RK (1997) Size, growth, development and survival of the planktonic larvae of Pomatomus saltatrix (Pisces: Pomatomidae). Ecology 78:2415-2431

Hoey AS, McCormick MI (2004) Selective predation for low body condition at the larval-juvenile transition of a coral reef fish. Oecologia 139:23-29

Houde ED (1974) Effects of temperature and delayed feeding on growth and survival of larvae of three species of subtropical marine fishes. Mar Biol 26:271-285

Houde ED (1987) Fish early life dynamics and recruitment variability. Am Fish Soc Symp 2:17-29

Houde ED (1989) Comparative growth, mortality, and energetics of marine fish larvae: temperature and implied latitudinal effects. Fish Bull 87:471-495

Houde ED, Zastrow CE (1993) Ecosystem- and taxon-specific dynamic and energetics properties of larval fish assemblages. Bull Mar Sci 53:290-335

Kingsford M, Finn M (1997) The influence of phase of the moon and physical processes on the input of presettlement fishes to coral reefs. J Fish Biol 51A:176-205

Lee TN, Williams E (1999) Mean distribution and seasonal variability of coastal currents and temperature in the Florida Keys with implications for larval recruitment. Bull Mar Sci 64:35-56

Lee TN, Clarke ME, Williams E, Szmant AF, Berger T (1994) Evolution of the Tortugas Gyre and its influence on recruitment in the Florida Keys. Bull Mar Sci 54:621-646

Masterson CF, Danilowicz BS, Sale PF (1997) Yearly and inter-island variation in recruitment dynamics of the bluehead wrasse (Thalassoma bifasciatum, Bloch). J Exp Mar Biol Ecol 214:149-166

McCormick MI, Hoey AS (2004) Larval growth history determines juvenile growth and survival in a tropical marine fish. Oikos 106:225-242

McCormick MI, Molony BW (1995) Influence of water temperature during the larval stage on size, age and body condition of a tropical reef fish at settlement. Mar Ecol Prog Ser 118:59-68

Meekan MG, Fortier L (1996) Selection for fast growth during the larval life of Atlantic cod Gadus morhua on the Scotian Shelf. Mar Ecol Prog Ser 137:25-37 
Meekan MG, Carleton JH, McKinnon AD, Flynn K, Furnas M (2003) What determines the growth of tropical reef fish larvae in the plankton: food or temperature? Mar Ecol Prog Ser 256:193-204

Milicich MJ (1994) Dynamic coupling of reef fish replenishment and oceanographic processes. Mar Ecol Prog Ser 110:135-144

Otterlei E, Nyhammer G, Flkvord A, Stefansson SO (1999) Temperature- and size-dependent growth of larval and early juvenile Atlantic cod (Gadus morhua): a comparative study of Norwegian coastal cod and northeast Arctic cod. Can J Fish Aquat Sci 56:2099-2111

Pepin P (1991) Effect of temperature and size on development, mortality, and survival rates of the pelagic early life history stages of marine fish. Can J Fish Aquat Sci 48: 503-518

Richardson WS, Schmitz Jr WJ, Niiler PP (1969) The velocity structure of the Florida Current from the Straits of Florida to Cape Fear. Deep-Sea Res 16S:225-234

Robertson DR, Swearer SE, Kaufmann K, Brothers EB (1999) Settlement versus environmental dynamics in a pelagic spawning reef fish at Caribbean Panama. Ecol Monogr 69: 195-218

Rombough PJ (1997) The effects of temperature on embryonic and larval development. In: Wood CM, McDonald DG (eds) Global warming: implications for freshwater and marine fish. Cambridge University Press, Cambridge, p 177-223

Rutherford ES, Houde ED (1995) The influence of temperature on cohort-specific growth, survival, and recruitment of striped bass, Morone saxatilis, larvae in Chesapeake Bay. Fish Bull 93:315-332

Searcy S, Sponaugle S (2000) Variable larval growth in a coral reef fish. Mar Ecol Prog Ser 206:213-226.

Searcy S, Sponaugle S (2001) Selective mortality during the larval-juvenile transition in two coral reef fishes. Ecology 82:2452-2470

Shima JS, Findlay AM (2002) Pelagic larval growth rate impacts benthic settlement and survival of a temperate reef fish. Mar Ecol Prog Ser 235:303-309

Sogard SM (1997) Size-selective mortality in the juvenile stage of teleost fishes: a review. Bull Mar Sci 60:1129-1157

Sogard SM, Olla BL (2002) Contrasts in the capacity and underlying mechanisms for compensatory growth in two pelagic marine fishes. Mar Ecol Prog Ser 243:165-177

Sponaugle S, Cowen RK (1994) Larval durations and recruitment patterns of two Caribbean gobies (Gobiidae): contrasting early life histories in demersal spawners. Mar Biol 120:133-143

Sponaugle S, Cowen RK (1997) Early life history traits and recruitment patterns of Caribbean wrasses (Labridae). Ecol Monogr 67:177-202

Editorial responsibility: Otto Kinne (Editor-in-Chief), Oldendorf/Luhe, Germany
Sponaugle S, Pinkard DP (2004a) Impact of variable pelagic environments on natural larval growth and recruitment of a reef fish. J Fish Biol 64:34-54

Sponaugle S, Pinkard DP (2004b) Lunar cyclic population replenishment of a coral reef fish: shifting patterns following oceanic events. Mar Ecol Prog Ser 267:267-280

Sponaugle S, Cowen RK, Shanks A, Morgan SG and 7 others (2002) Predicting self-recruitment in marine populations: biophysical correlates and mechanisms. Bull Mar Sci 70: 341-375

Sponaugle S, Fortuna J, Grorud K, Lee T (2003) Dynamics of larval fish assemblages over a shallow coral reef in the Florida Keys. Mar Biol 143:175-189

Sponaugle S, Lee TN, Kourafalou V, Pinkard DP (2005) Florida Current frontal eddies and the settlement of coral reef fishes. Limnol Oceanogr 50:1033-1048

Suthers IM, Taggart CT, Kelley D, Rissik D, Middleton JH (2004) Entrainment and advection in an island's tidal wake, as revealed by light attenuance, zooplankton, and ichthyoplankton. Limnol Oceanogr 49:283-296

Takasuka A, Aoki I, Mitani I (2003) Evidence of growthselective predation on larval Japanese anchovy Engraulis japonicus in Sagami Bay. Mar Ecol Prog Ser 252:223-238

Thorrold SR, Shenker JM, Mojica R Jr, Maddox ED, Wishinski E (1994) Temporal patterns in the larval supply of summer-recruiting reef fishes to Lee Stocking Island, Bahamas. Mar Ecol Prog Ser 112:75-86

Victor BC (1982) Daily otolith increments and recruitment in two coral-reef wrasses, Thalassoma bifasciatum and Halichoeres bivittatus. Mar Biol 71:203-208

Victor BC (1986a) Delayed metamorphosis with reduced larval growth in a coral reef fish (Thalssoma bifasciatum). Can J Fish Aquat Sci 43:1208-1213

Victor BC (1986b) Larval settlement and juvenile mortality in a recruitment-limited coral-reef fish population. Ecol Monogr 56:145-160

Vigliola L, Meekan MG (2002) Size at hatching and planktonic growth determine post-settlement survivorship of a coral reef fish. Oecologia 131:89-93

Warner RR, Robertson DR (1978) Sexual patterns in the labroid fishes of the western Caribbean I. The wrasses (Labridae). Smithson Contrib Zool 254:1-27

Wilkinson L (1992) SYSTAT: the system for statistics. SYSTAT, Evanston, IL

Wilson DT, Meekan MG (2001) Environmental influences on patterns of larval replenishment in coral reef fishes. Mar Ecol Prog Ser 222:197-208

Wilson DT, Meekan MG (2002) Growth related advantages for survival to the point of replenishment in the coral reef fish Stegastes partitus (Pomacentridae). Mar Ecol Prog Ser 231:247-260

Submitted: July 14, 2005; Accepted: November 17, 2005

Proofs received from author(s): January 20, 2006 